\title{
The San Francisco Peace Treaty and the Problems Regarding Japan's Exemption from Blame for the Colonization of Korea
}

\author{
YI Tae-Jin \\ Seoul National University, Seoul, Korea
}

\begin{abstract}
The 1951 San Francisco Peace Treaty was the one and only international opportunity that would have allowed demanding for Japan's responsibility of the colonization of Korea. However, the United States did not demand of such to be done. Soon, Korea and Japan resumed their diplomatic relationship and had their first summit in 1952. After numerous negotiations, finally in 1965, the "Korea-Japan Treaty" was agreed upon. Even in this treaty, the interpretation of the colonization was different for both countries and ultimately resulted as an unresolved issue. This is because of the Japanese dependence to the San Francisco Peace Treaty. On the other hand, the League of Nations, founded in 1920, believed that the systematization of international law was vital to keeping international peace. Therefore, they put much effort in and successfully carried out the codification of international law. The "Report on the law of Treaties" which was completed in 1935, noted that the "1905 Protectorate Treaty", which was the ultimate treaty that led to Korea being annexed by the Japanese, was one of the three treaties that had no effective standing. This decision was carried out to the International Law Commission of the United Nations in 1963 and became a Resolution after being submitted to the General Assembly in the end of the same year. Using the decisions of the League of Nations and the United Nations as evidence, this paper critically reviews the San Francisco Peace Treaty's lack of reviewing the Japanese responsibility of the colonization of Korea.
\end{abstract}

Keywords: Protectorate Treaty of November 1905, International Peace activists in 1900s, The Second Hague Peace Conference, William T. Stead, Francis Rey, James Garner, Manley O. Hudson, Harvard Draft Convention on the Law of Treaties

\section{Introduction}

In the first half of the 20th century there were three major wars-namely the Russo-Japanese War (1904-1905), World War I (1914-1918), and World War II (1937-1945). These three wars shared a common post-war outcome: either the hosting of a global peace conference or the establishment of a global peace organization After the Russo-Japanese War, the Second Hague International Peace Conference (1907) was held, and World Wars I and II led to the formation of the League of Nations (1920) and the birth of the United Nations (1945), respectively. However, while all three events were nominally conducted for the sake of world peace, they cannot be ranked in the same category. The Second Hague International Peace Conference was supposedly held for the promotion of peace, but it was unable to go beyond being merely a venue for the world powers vying for imperialistic gains. In contrast, the League of Nations is regarded as the first international organization in human history geared toward peaceful coexistence, and the United Nations is an expansion and

YI Tae-Jin, Ph.D., Emeritus Professor, The Korean Institute for Historical Research, Seoul National University. 
reorganization of the former. Above all, the League of Nations and the United Nations have set their missions as aiming for the total liberation of nations formerly colonized by the imperialistic world powers in the past, thereby marking a turning point in history.

The 19th and 20th centuries are referred to as the age of imperialism. It was an era when the world powers were vying for colonies via diplomacy backed by military might. However, occurring concurrently was the widespread emergence of an international peace movement initiated by a core of European and American intellectuals to counter the imperialistic powers. In the latter half of the 19th century, international legal societies emerged in several advanced countries. In 1901, Nobel Peace Prize was established, to select and award persons of merit in the international peace movement. At around the same time, Andrew Carnegie also began his philanthropic efforts to promote peace. The establishment of the League of Nations in 1920 was a significant historical milestone which emerged from this world peace movement. Unfortunately, in the midst of this trend toward global peace, Korea was robbed of its national sovereignty and annexed by Japan. Initiating war against Russia for the purpose of "exclusive rule over" Korea, Japan proclaimed this war as being for the advancement of East Asian Peace, cognizant of the peace movement in the West. But this was nothing but false peace advocacy for the usurpation of the neighboring country's sovereignty.

Japan, starting with an agreement permitting Japanese use of Korean military bases at the outbreak of the Russo-Japanese War in February 1904, forced Korea to sign in succession altogether five agreements regarding national sovereignty, culminating in its annexation of Korea in August 1910. This process, as can be seen in detailed description later, progressed gradually with the deployment of military forces in the Korean peninsula and the imposition of martial law, followed by the coerced signing of treaties backed by military might, and the subsequent usurpation of national sovereign rights one by one. The unjustness and illegality of these actions were addressed at the abovementioned three global peace events but to no avail for the restoration of national sovereign rights. Japan, as a formal participant of these events, was able to employ heavy-handed countermeasures to prevent the success of such protest efforts. Following the conclusion of World War II, hopes were most high since unlike the situations of the first two events, Japan was now on the side of the defeated nations. However, at the signing of the 1951 San Francisco Peace Treaty with Japan, the original agenda of punishing fascism was pushed aside and instead Cold War concerns took precedence. As such, no charge was made to hold Japan responsible for the process of usurping the sovereignty of Korea and the numerous criminal activities committed during the period of colonial rule.

The San Francisco Peace Treaty system has been the basic framework regulating the international relationship among the East Asian nations to this day. The unsettled state of affairs regarding historical issues as described above is becoming a fundamental source of unrest among the three East Asian countries. Given that such regional unrest and insecurity cannot be left unaddressed, the rectification or improvement of the situation must deal with urgently. In its codification work on treaty law in 1935, the League of Nations cited the 1905 protectorate treaty when Japan deprived Korea of its diplomatic power as one of three treaties in history that could not go into effect. The United Nations accepted the League of Nations' verdict as such consummated it by having it adopted as the General Assembly resolution in 1963.

The San Francisco Peace Treaty focused on countering the communization of East Asia, strictly falling under situational logic. In contrast the judgments by the League of Nations and the United Nations were presented as a goal to be pursued permanently by human society. If we are determined to overcome the 
limitations of San Francisco Treaty framework, there is need for closer examination of the international legal judgments by the two world organizations.

\section{The Origins of Japanese Imperialism}

In the West, the term "imperialism" came into use starting around 1870. In Japan, however, in the midst of self-congratulation on Japan's victory in the Russo-Japanese War, thereby joining the ranks of the world powers, there appeared the assertion that in Japanese history the concept of "imperialism" had existed already in ancient times.

In 1893 the journalist Tokutomi Soho (德富蘇峰) published the book Yoshida Shoin (吉田松陰), which drew public attention. In his youth in the 1870s he was a champion of civil rights; later he published Kokumin no Tomo (“The People's Friend” 國民の友) and Kokumin shimbun (“The People's Newspaper” 國民新聞). The book's subject Yoshida Shoin was a warrior from Chōshū (長州) Domain(藩) in western Japan during the late (Tokugawa) shogunate period. He clamored for the establishment of a centralized authoritarian Emperor system and was executed by the shogunate. Though he died early at a young age, his legacy was carried out by the pupils taught at Shoka Sonjuku (松下村塾), a small school he founded in Hagi (萩) the capital city of Chōshū Domain. These pupils played a major role in Meiji Restoration, establishing the so-called Chōshū Meiji oligarchy. In his book, Tokutomi in the beginning likened Yoshida Shoin to Giuseppe Mazzini of Italy, inheriting his spirit and advocating the need for a Second Restoration. Even then, he remained a civil rights advocate. However, by the time the revised edition of the book was published in 1908 after the Russo-Japanese War, he had completely transformed himself into a genuine nationalist.

Shortly after publishing the first edition of his book Yoshida Shoin as the preparations for war against China began to materialize, Tokutomi began to display his transformation into a nationalist clamoring for a "Great Japan" through his newspapers and magazines. Once the Sino-Japanese war actually broke out, he attached himself closely to the Chōshū military group, obtaining the war information in advance. He reported incendiary news articles using such advance war information, thereby making his newspaper one of the most influential papers while making himself into a political figure (YI, 2014).

Japan proved victorious in the war with China, which ceded the Liaotung peninsula. However, combined triple intervention from Russia, France and Germany forced Japan to give up control of Liaotung. Tokutomi Soho roared with rage and clamored for overthrowing "the white warlords (白閥)", stirring up his countrymen to take vengeance on Russia, through his media. Ten years later, when the Russo-Japanese War broke out, Prime Minister Katura Taro (桂太郎) appointed him to take complete charge of public relations toward the entire world regarding the war. Upon winning that war, Japan acquired the exclusive right to reign over Korea as intended and advanced into southern Manchuria. At the "urgent request" of General Nogi Maresuke (乃木希 典) and with the help of many of the Shoka Sonjuku pupils, he published a revised edition of his book. In the revised book the contents were changed drastically into nationalistic ones. The comparison of Yoshida Shoin with Mazzini was eliminated at the request of the major figures of Chōshū Meiji oligarchy, who disapproved comparing their teacher and Japan's "hero" Yoshida Shoin with a foreigner.

This time, Tokutomi Soho depicted Yoshida Shoin as the historical figure who revived the emperor's way principle “皇道主義”, known since ancient times in Japan. Emphasizing Yoshida Shoin's execution for advocating the revival of the Emperor system at the end of the shogunate, he envisioned an ultimate world of the emperor's way principle, radically believing that everyone would readily sacrifice their lives without 
hesitation just like Shoin. He asserted, "Under the emperor, there is no shogunate, no fiefdoms. Only the Japanese Empire exists...", affirming to support the extreme emperor system. He determined that the birth of Japan's ancient emperor system and the Meiji Restoration based on Shoin's spirit as the proudest events in Japanese history. He even praised Yoshida Shoin as the embodiment of Japanese man and his life as the national poetry imbued with blood flowing. The revised edition of Yoshida Shoin became one of the leading national books, widely read by all the subjects of Japanese Empire such that it continued to be printed repeated up to the 27th printing as of 1942 .

In 1853, Yoshida Shoin was quite shocked at the sight of U.S. Commodore Matthew Perry's fleet, equipped with steamships and naval guns that Japanese armor could not withstand at all. In the following year when Admiral Perry's fleet came to Japan again to conclude the peace treaty, he went on board the ship, asking for secret passage. This was revealed to the shogunate and he was sent under escort to Chōshū to be put in prison. His attempt for the secret passage on board was meant only to learn Western technology in person to defend Japan against Western might and strengthen its defenses. In prison he wrote "Imprisonment Record" (幽 贝錄). In 1858, he protested strongly against the shogunate for signing the Treaty of Peace, Amity and Trade with U.S. without seeking the Emperor's consent, and this led to his death by decapitation in the following year. Thereafter, "Imprisonment Record" was used by his pupils as the bible for their foreign expansionist policy from the perspective of the survival of the Japanese Empire.

Yoshida Shoin put strong emphasis in particular on Japan's being an insular nation. In an era of ships with sails, the surrounding seas served as girding ramparts, whereas in an era of steamships Japan became a defenseless country, open all around. In order for Japan to overcome this weakness, he stressed Japan could not help but strengthen itself rapidly and occupy its neighboring countries in advance ahead of Western powers. To counter Russia coming down from northeast he urged to cultivate Hokkaido first and then advance to the Kamchatka peninsula. Toward the west, he advocated advancing into Ryukyu and Taiwan, and to the north, advancing into Korea and Manchuria. As for Korea, in particular he insisted on its subjugation once again in view of its history of having paid tribute to the Yamato court in ancient times. Following (these advances) were to be Mongolia, China, Australia, and America. Mongolia, in order to block the Russian southward advance, and China, as a country garnering the keen interest of all the global powers, were two countries Japan could not afford to leave alone. Regarding "the large continent" Australia, even though Great Britain was advancing there at that time, it could control only one-tenth or less of the continent, compelling Japan's need to make inroads he asserted. As for the U.S., he clamored for advancing to Australia as well as strengthening its control over the Pacific to defend against any U.S. move toward Japan.

The Chōshū Meiji oligarchy, with Yoshida Shoin's pupils at the core, aligned with the Satsuma oligarchy to consolidate an unshakable ruling foundation. In the process those such as Katsu Kaishu (勝海舟) who favored building Japan as a trade superpower pursuing peaceful coexistence had their influence diminished. Japan's international aggression policy led by the Chōshū Meiji oligarchy followed the same strategy of the "Imprisonment Record", even to the degree of using the same sequence. Japan went on to colonize Hokkaido, annex the Ryukyu Islands, advance to Taiwan to start the Sino-Japanese War in 1894, and then initiated the Russo-Japanese War in 1904 to thereby successfully advance into Korea and Manchuria. The Sino-Japanese War in 1937 and the Pacific War in 1942 were the last events in the sequence shown in "Imprisonment Record", aimed at gaining control over the Pacific. 
Japan continuously maintained both politically and academically that its annexation of Korea was inevitable, in response to changes in the world order. However, looking squarely at the correlation between the reverence for "Imprisonment Record" and implementing "Imprisonment Record" into action, one can only conclude that not only Japan's annexation of Korea but also the provocation of Pacific War was entirely planned from the beginning. Korea was already striving to become a modern country by adopting Western technology and civilization from the early 1880s. From 1897 the political system of the state was changed to the Great Han Empire to add momentum to modernization. However, as its territory became a battleground amid the Russo-Japanese War, Korea was forced to sign the Protectorate Treaty with Japan in 1905 and ended up de facto losing all of its national sovereign rights. To stop this, a drive to restore national sovereignty was spurred targeting at the eight countries that signed the Treaty of Peace, Commerce and Navigation with Korea. A special envoy was sent to the Second Hague Peace Conference to expose the reality of Japan's aggression to international society, but this proved to be of no avail and in the end Korea was forcibly annexed by Japan in August 1910. Japan robbed Korea of its sovereign rights through the occupation of Korean peninsula by force following the Russo-Japanese War.

\section{Recent Developments in Studies on the "Illegality” of Japan's Usurpation of the Sovereignty of Korea}

\section{Studies on Flaws of the Formalities of the Treaties}

Studies on Japan's usurpation of the sovereignty of Korea have been conducted in various ways. Critical studies through the 1980s placed emphasis on the fact of the intimidation of the Korean Emperor and ministers through the deployment of military police and the police at the time of the signing of the protectorate treaty in 1905 , using this as the basis for nullification of this treaty by international law. On the other hand, Japan insisted there was no illegality in the annexation treaty in 1910 at all because the Korean Emperor consented to it. Both sides were limited by the lack of plausible theories or sufficient substantiating data. However, starting from the early 1990s, from the Korean side there began to emerge studies based on empirical verification and investigation of the original treaty documents, pointing out the many flaws or grounds for disqualification of the treaties resulting in the usurping or relinquishing of national sovereignty. Representative of these is $\mathrm{Yi}$ Tae-Jin's study scrutinizing the original documents of five international treaties among the Great Han Empire government documents stored at Gyujanggak Archives in Seoul National University, which pointed out the following flaws (YI, 2016-4). ${ }^{1}$

(1) All five of these treaties dealt with national sovereignty, but only one of them - the Annexation Treaty on 1910 conforms to the requisites of the formal treaty (the appointment of the plenipotentiary, the original treaty by mutual agreement, instruments of ratification by sovereigns of both sides). Even the Treaty of Annexation of 1910 lacked the Korean Emperor's signature and the state seal on the "Imperial Mandate" that corresponds to the Korean Emperor's instrument of ratification;

(2) The other four treaties, being informal treaties, adopted the formalities of "Agreements". In particular, the Agreement of August 22, 1904 was nothing but a mere "memorandum", but it was disguised to be regarded

\footnotetext{
1 The five treaties were: (1) The Korea-Japan Protocol (Japan-Korea Protocol) of February 23, 1904; (2) (The First) Korea-Japan Agreement (Japan-Korea Agreement) of August 22, 1904; (3) The Second "Protectorate Treaty" (Japanese-Korean Agreement) of November 17, 1905; (4) Korea-Japan Agreement (Japan-Korea Agreement) of July 24, 1907; (5) The Treaty of Annexation of August 29, 1910. The names in ( ) are the names used by Japan.
} 
as a formal treaty by being titled "Agreement" in the English version document to be sent to the governments of the Western powers, even though the original memorandum lacked such a title. If the governments of those countries with diplomatic relations with Japan received this tampered English version and regarded this mere memorandum as an actual diplomatic agreement, albeit informal, there is a strong possibility that they might have perceived Korea as having already relinquished its diplomatic authority to Japan, in light of the specified content in Article 3-namely, the Korean Government is to consult with the Japanese Government in advance on all diplomatic matters. In fact it is noteworthy that immediately after this "Agreement", the Second Anglo-Japanese Alliance and the Katsura-Taft Agreement were concluded;

(3) As for the Protectorate Treaty in 1905, even though the space for the title of the treaty was left blank in the original, the English version contained the added title of "Convention", making this protectorate treaty look as if it were a formally concluded treaty. The fact that this treaty concerning national sovereignty-a matter of utmost concern - specifies that the Japanese Government is to send the Japanese Resident-General to exercise Korean diplomatic authority in person and yet harbors such a grave defect amounting to tampering with the document amounts to credible evidence that the treaty was not secured in the usual manner.

(4) The "Japan-Korea Agreement" of July 1907 empowered the Japanese Resident-General to supervise the Korean Government's internal administration. Despite being an agreement with such gravity, this was concluded by having the Korean representative (cabinet Prime Minister Lee Wan-yong), despite lacking full power granted by the Korean Emperor, merely sign and seal on the agreement document prepared by Ito Hirobumi, the Japanese Resident-General in Korea at that time.

It is assumed that the results of such studies regarding the circumstances and issues in the process of formulating the original documents of the relevant treaties, as described above, might have shocked Japanese academic circles. Japan's renowned monthly magazine Sekai (世界 “World”) carried an article on such study results of Yi Tae-Jin and created the project of a “Japan-Korea Talk" (日韓對話) corner, where the opinions of concerned Japanese specialists were solicited, spurring the exchange of the pros and cons on the article over a span of seven times. This project has been highly regarded for having taken the debate on historical issues between Korea and Japan to a new level.

Corroborative studies on the original documents of the pertaining treaties by Korean academics have continued (YUN, 2011). In 2010 at the 100th anniversary of Korea's Annexation by Japan, Yi Tae-Jin organized his study results and presented the following findings to academia. ${ }^{2}$

(1) There is considerable evidence of Japan's exercising of coercion traceable in the different sorts or states of the papers used in the original texts of the treaties. For instance, for the Japan-Korea Protocol of February 1904, the Korean side used paper with “Great Han Empire Bureau of Foreign Affairs” (大韓國外部) printed on it, whereas the Japanese side used paper with “The Japanese Legation in Korea” (駐韓日本公使館) printed on it. The treaty text was bound with yellow lace by Korea and blue lace by Japan, respectively. The Great Han Empire Bureau of Foreign Affairs, though conceivably coerced, is assumed to have taken part in signing the treaty in the normal manner, most likely because of the phrase guaranteeing Korea's independence specified in Article 3;

(2) The "First Japan-Korea Agreement" of August 1904 was essentially only a "memorandum"; hence, there was no treaty text written in each country's language to be kept by both sides. Only one document,

${ }^{2}$ Yi Tae-Jin, “Treaties Leading to Japan's Annexation of Korea-What are the Problems?”. Korea Journal, vol. 56, 2016-4, Winter. The Korean National Commission for UNESCO. The paper focuses on the problems of the treaty documents. 
prepared in Japanese language and listing three items without any commissioning of the representatives, survives, was housed in the Diplomatic Archives of the Ministry of Foreign Affairs of Japan (日本外交史料 館);

(3) As for the Protectorate Treaty of November 1905, the Japanese language version, in the same manner as in (1), used paper with "The Japanese Legation in Korea" printed on it and was bound with blue lace. However, the Korean language version used paper without "Great Han Empire Bureau of Foreign Affairs" printed on it and was bound with blue lace the same way as the Japanese version. This is obvious evidence that Japanese side unilaterally prepared and filed this treaty;

(4) As for the "Japan-Korea Agreement" of July 1907, the Japanese language version used paper with "The Japanese Legation in Korea" printed on it and was bound with green lace. The Korean version used paper without any Korean government name printed on it and was not bound with any lace;

(5) As for Korea Annexation Treaty of August 1910, the Korean and Japanese language versions are very similar to each other, looking like twins. Both used white paper, were bound with white lace, and also were written in the same style of handwriting for both Korean and Japanese. In fact, it was later revealed that both were handwritten by Maema Kyosaku (前間恭作) who was in charge of Korean language interpretation for envoys or diplomatic ministers starting from the Treaty of November 1905 (YUN, 2011). His proficiency in Korean language was such that after his retirement from office, he studied the Hunminjeongum (訓民正音 "Correct Sounds to Instruct People" = the compiled study of the Korean alphabet).

As stated above, the state or condition of all the original texts of the treaties except for (1) provides substantive evidence to confirm the Japanese coercion on signing treaties, and academia should continue to pay close attention to this issue.

\section{Forced Treaties Under Martial Law}

The Imperial Japanese Army compiled three historical narratives pertaining to the conduct of the Russo-Japanese War as follows (Ooe Sinobu, 1983).

(1) Meiji Reign, 37th-38th years, Japan-Russia War History (明治三十七八年日露戰史, 10 volumes with addendum of 10 maps 1912-1914) compiled by the General Staff Office;

(2) Meiji Reign, 37th-38th years, Annals of the Army (明治三十七八年陸軍政史, 10 volumes, 1911) compiled by the Army Ministry;

(3) Classified, Meiji Reign 37th-38th years War Statistics (明治三十七八年戰役統計, 6 volumes, 1911) compiled by the Army Ministry.

The first (1) narrative was compiled to record the command structures during the war by the General Staff Office, the wartime military supreme command. The second (2) narrative contained the annals of war except for the command structures compiled by the Army Ministry. The third (3) narrative contained war statistics compiled separately. The first (1) was widely used after its publication as a public resource, but the second (2) was highly classified material within the Army Ministry and its existence was not made known to concerned Japanese academic circles even after the Japan's defeat in 1945. In 1983, when its repeated carved templates printing version (復刻本, published by Shyonando shoten, 湘南堂書店) came out, only then did it draw the attention of concerned researchers. It first became known to Korean scholars at an international conference held in November 2015 when Professor Inaba Chiharu (稻葉千晴) of Meijo University (明城大學) presented a paper on "The Japanese Occupation of Korea in February 1904" which utilized the (2) narrative. 
During the Russo-Japanese War martial law was declared as is recorded in narrative (2) in the addendum of Volume 1 and Volume 8. It is on record that Japanese Army in Korea, deployed as the First Army simultaneously as the outbreak of war, enforced martial law in Korea not only during "wartime", but also during the time of "peace" rendered by Portsmouth Peace Treaty next year. If the Japanese Army, in the course of its war with Russian, took advantage of the territory of the third-party nation Korea and imposed martial law upon the Korean people and society, and then habitually indulged in killing and injuring Korean people under the pretext of having handed over the classified information to the Russian Army, which could pose a profound problem (YI, 2016). In January 1904, just prior to the outbreak of the war, the Government of the Great Han Empire declared itself to be a neutral state in the conflict; however, the Japanese Army completely ignored this. The Korean peninsula was not the actual battlefield between Japanese and Russian forces. However, a large number of forces in the Japanese Army's First Army in Korea were deployed along the Yalu and Tumen rivers and the northern territorial region, while in the east a landing site for troops and military supplies was established at Youngheung Bay. Within areas of military deployment, whenever a military operation begins any military order from the commanding system constitutes military law, the same as martial law. Although the Korean peninsula was not involved with any active battle, the line of defence was established as described above to block Russian forces from moving into the peninsula, thus creating the situation where Korea was essentially fortified to be on constant vigilance. Moreover, even after the cessation of the war in June 1905, the forces of several divisions were not evacuated and remained stationed in the Korean Peninsula, with "military law" and "military order" enacted separately to keep the wartime martial law situation intact. ${ }^{3}$ Wartime military orders (martial law) dealt most likely with matters pertaining to military installments used during the war, dead bodies, clothing, and controlling time, whereas peacetime military law and military discipline dealt more often with detecting espionage activity within the pertinent area, destruction of traffic facilities, damaging provisions and munitions and subjecting violators to punishment.

Among the abovementioned treaties pertaining to national sovereignty, the “Japan-Korea Protocol” (議定 書) and the “First Japan-Korea Agreement of August in 1904” (第1次日韓協約) were forced upon Korea in the midst of war, but the "Protectorate Treaty" of November 1905 was forced under "the military discipline of the Japanese Army Stationed to Korea", equivalent to the peacetime martial law, invoked on July 3, 1905, that same year. This military discipline was strengthened further to become the "Japanese Army Stationed to Korea military order and its violation judgment rules" on May 28, 1906, leading to the coerced "Japan-Korea Treaty of 1907" which robbed Korea of internal administration rights by the Residency-General.

Surprisingly, Meiji Reign, 37th-38th years, Annals of the Army Administration (明治三十七八年陸軍政 史) Volume 8 contains the report pertaining to the coerced conclusion of the Protectorate Treaty of November 1905, sent to the Imperial General Headquarters by the Commander of the Japanese Army Stationed to Korea, Hasewgawa Yoshimichi (長谷川好道). ${ }^{4}$ It is dated as of November 28, 10 days after the coerced treaty.

\footnotetext{
${ }^{3}$ The relevant military laws and military orders were as follows: (1) Japanese Army Stationed to Korea 韓國駐笭軍 military law (proclaimed on July 3, 1905); (2) Japanese Army Stationed to Korea military law regulations for violation judgments (proclaimed on July 3, 1905); (3) Jinhaeman Bay fortifications military law (proclaimed on August 1, 1905, and implemented on same day); (4) Jinhaeman Bay fortifications administrative rules (proclaimed on August 13, 1905, and implemented on same day) (5) Yeongheungman Bay fortifications military law (proclaimed on July 13, 1905); (6) Japanese Army Stationed to Korea military order discipline and violation judgment rules (proclaimed on May 28th, 1906.)

${ }^{4}$ Volume 8, pp. 263-264. November 28, 1905. "The Chief of the General Staff received the transmitted report by the Commander of the Japanese Army Stationed to Korea regarding the conclusion of the Korea Protectorate Treaty as follow (Documents No. 2368).
} 
The Commander of the Japanese Army Stationed to Korea is the chief martial law administrator. If he proceeded to get the treaty signed by directing the troops under his command, this could well be the clearest evidence establishing the fact that the treaty was signed through coercion. This report recorded in great detail the proceedings starting from the time of receiving the assignment from the Imperial General Headquarters to help the special envoy Ito Hirobumi (伊藤博文) in concluding the treaty to the time when the mission was accomplished as of 1 a.m. on November 18th, as well as the detailed information as to the deployment of his troops on the day the treaty was concluded. The report states that he saw the necessity of showing armored might and ordered infantry units to be placed on continuous patrol in Seoul, while a cavalry regiment and an artillery battalion were mobilized into Seoul to go around the city, causing the Korean people shudder. He also disclosed that as the Korean Emperor and his high officials were opposing the conclusion of the treaty by delaying its signing, he had additional heavily armoured forces dispatched into the city to prevent the Korean crowd from joining the Korean Emperor and his officials. In addition, he reported that he accompanied the special envoy Ito to the location of the Korean Emperor and stayed there from 8 p.m. on November 17th to the time of "the treaty's full conclusion" at 1 a.m. on November 18th. At the end of his report on the proceedings surrounding the treaty's conclusion, he described his contribution as follows:

I, your subordinate, hereby report that under the brilliant afterglow of Your Majesty (Emperor), amid the commotion of people in Seoul, and without single drop of blood spilt nor a single perpetrator committing a crime, I have fulfilled the privileged duty to contribute to the conclusion of such a profound matter determining national sovereignty, and I also mention the special efforts of special envoy Ito including his diplomatic officers and policemen. (p. 266)

The Japanese Army Stationed to Korea was encamped at a site about two kilometers away from the center of Seoul (Yongsan area at present). Hereafter, this Army repeated the same role during the usurpation of Korea's internal administration rights in July 1907 and also the coerced annexation in August 1910.

The Japanese Government allowed Army Minister Terauchi Masatake (寺內正毅) to concurrently become the Resident-General of Korea in May 1910. The preparation for the annexation of Korea was carried out primarily by his Army Ministry (YI, 2016). After finishing the preparation for the annexation in Tokyo, he arrived in Seoul at the end of July to oversee the implementation of annexation. He then became the first Governor-General of the Japanese Government-General of Korea upon its establishment as the government machinery overseeing over the colony. The Governor-General in Korea is stipulated as being directly subordinated to the Emperor, with the Army Minister or Navy Minister being appointed to that post. The aforementioned Meiji Reign, 37th-38th years, Annals of the Army (明治三十七八年陸軍政史) was published in his second year as the Governor-General in Korea under his title of Army Minister in 1911.

The Empire of Japan continued to keep the martial law, which was first declared by the Japanese Army in Korea in February 1904 at outbreak of the Russo-Japanese war, in effect even after concluding the war, which led to its annexation through coercion primarily by its Army. The treaty was a diplomatic agreement that was only perfunctorily concluded with Japan merely because of concerns over the attention of the great powers of Europe and America. However, there remained numerous defects and flaws engendered by the Korean Emperor and his subjects which serve as the substantiating evidence of coercion by Japan. 


\section{Judgment on the "Protectorate Treaty of November 1905" by the League of Nations and the United Nations}

Views on the Protectorate Treaty of November 1905 by the International Peace Activists in 1900s

As was stated in the Introduction, toward the end of the 19th century, there was a rising movement among Western intellectuals who took the perspective of international peace and criticized the world powers' fierce scramble for colonies. Criticism of the Protectorate Treaty forced upon Korea by Japan in November 1905 emerged immediately. The French international law scholar Francis Rey published his article, "La Situation Internationale de la Corée" (The International Law Situation of the Great Han Empire) in a collection of dissertations on international public law (Revue Generale de Droit International Public, Vol 13, Paris) in 1906. He scrutinized the inconsistent relationship between the "Protocol of February 23, 1904" and the "Protectorate Treaty of November 1905". He placed emphasis on the stipulation in Article 5 of the "Protocol" that both Japan or Korea should not conclude any treaty with a third-party country that went against the intent of this protocol without mutual consent. According to this stipulation, the Treaty of Portsmouth signed by Japan with Russia on September 5, 1905, was illegitimate since Japan did not secure the consent of Korea. He asserted that taking the advantage of recognition by powerful countries to secure the protectorate or measures to control Korea without getting the consent from Korea beforehand was beneficial only to Japan and a violation of the promise made to Korea. In any treaty, the stipulations in its Articles are to be reciprocal. He raised the question that if a strong nation can get out of the stipulations in a treaty with a small and weak nation at will ("a savolonte"), what is the need of signing the treaty at all?

In addition, he also pointed out that Japan had promised to guarantee Korea's independence-once in the Treaty of Shimonoseki signed in April 1894 and again in the "Protocol" (of February 1904), only to conclude the Protectorate Treaty in November 1905 just one year and nine months later, constituting an inconceivable contradiction. He wrote that a protective relationship and independence were completely incompatible. Lastly, he pointed out the fact Japan had used the threat of military force against Korea to get the treaty signed. He said the fact that upon the Korean Emperor's strong refusal to sign the treaty, the commander of the Japanese Army Stationed to Korea, Hasegawa Yoshimichi, then led his troops to the meeting place to coerce the Korean side, was really a shameful act of violence to have been perpetrated by such a civilized nation as Japan.

Immediately after the "Protectorate Treaty" was forcibly signed, the Korean Emperor engaged in diplomatic activity to nullify the treaty, sending personally written letters to the heads of states with whom diplomatic relations had been established, informing them that he himself had never approved the treaty. He conducted friendly diplomacy with the heads of those world powers including the U.S., England, France, Germany, Russia, Austria, Hungary, Italy, Belgium, and China. He did not forget to dispatch special envoys to the Second Hague Peace Conference in June 1907. It is noteworthy that the renowned British journalist William Thomas Stead (1849-1912) showed an enthusiastic response to the activities of the three special envoys at the conference.

William Stead is highly regarded as the meritorious person who transformed the British newspapers from being geared toward gentlemen to being geared toward ordinary citizens. In addition, he was an avid international peace activist who would not stand by idly when small and weak countries were falling victim to the world powers' imperialism. He made his reputation with his articles championing international justice at the time of the first Hague Peace Conference. During the Second Peace Conference he stayed in Hague for four 
months, publishing the exclusive newspaper for the Peace Conference, Courrier de la Conference (Peace Conference News). He was so profoundly impressed by “The Statement of Reason for Appeal” (控訴詞) announced by the three Korean special envoys that the entire text of the statement was printed in his newspaper. ${ }^{5}$ Moreover, as the representative of all the nations' reporters, he invited the Korean envoys to a meeting presided over by himself to hear about the Korean situation in greater detail. At this meeting, the Korean representative Yi Wi-jong made a speech in fluent French which received an ovation, resulting in the contents of his speech being reported on in detail under the title "A Plea for Korea" by the reporters' newspaper Haagsche Courant (Movements in Hague). Thus, the intellectuals engaged in international peace movement and the Western media did not side with Japan.

\section{The Report on the Law of Treaties by the League of Nations (1935) and the Protectorate Treaty of 1905}

The American Society of International Law (ASIL) was founded in $1906 .{ }^{6}$ Since its foundation, it has striven over a century for the realization of international peace so fervently that it has come to be regarded as "a cornerstone of a just and peaceful world". It is the fruitful result of the endeavors by a group of lawyers with the conviction that striving for the resolution of international disputes through peaceful dispute settlement mechanisms rather than resorting to war is appropriate. Starting in 1895 those who were involved in the establishment of U.S. diplomatic policy held meetings repeatedly and finally in 1905; at its 11th meeting, the establishment of the society and publication of the American Journal of International Law were agreed upon. In January of the following year, "The Constitution of the American Society of International Law" was adopted formally in the office of the New York City Bar Association. This society was started with the intention of contributing directly to governmental foreign policy directly and it was unique in that it used to hold its Annual Meetings regularly in White House with the President delivering a speech. ${ }^{7}$ This such effort within the U.S. by this group of opinion leaders to establish foreign policy striving for the accomplishment of international peace order led to the foundation of The League of Nations through President Woodrow Wilson.

President Woodrow Wilson inaugurated as the 28th President of the United States in March 1913. Wilson himself was a pacifist. In 1915, one year after the outbreak of World War I, he had his advisor Colonel House (Edward M. House) inquire about the will of the governments of powerful European countries, and he also established the study group "The Inquiry" as a preparatory instrument seeking the way to achieve postwar order, recruiting a large number of university professors. In October 1918, a total of 123 professors assigned in 16 branches through the so-called "The Black Book" participated and took part in its activities (Choe, 2014). Six of the branches were for important fields, such as international law, diplomatic history, economics, and others, and the other 10 branches were based on regions including Africa, the Austro-Hungarian Empire, the Balkan States, the Far East, and other. The professors were assigned according to their specialties. In particular, eight

\footnotetext{
${ }^{5}$ Stead initiated the switch from the large and inconvenient broadsheet format used by early British papers to the tabloid format. He also published The Review of Reviews, as a newspaper urging the government to pursue politics for the benefit of the people. He reached an agreement with American media, but on his way to New York, he perished with the sinking of the Titanic in 1912. In that year he was nominated as a candidate for the Nobel Peace Prize. Mooney, Bel (25 May, 2012). "High morals and low life of the first tabloid hack: Muckraker: the Scandalous Life and Times of W. T. Stead by W. Sydney Robinson". London: Mail Online. Retrieved 4 November 2012. British Library-Press and Policy Centre-The newspaper giant who went down with the Titanic - Conference at the British Library to mark centenary of the death of W. T. Stead.

${ }^{6} \mathrm{https}: / /$ www.asil.org/about/asil-history.

7 Ibid. The first president, Elihu Root was the U.S. Secretary of State at that time. When the Great Han Empire gave notification that the First Japan-Korea Agreement (1904.8.) and the Second Japan-Korea Agreement (Ulsa Treaty, 1905.11.) were illegally forced upon it, he did not ascertain the truth and made the mistake of ignoring the Great Han Empire's protest.
} 
members were assigned to the international law branch, recognizing its prime importance. ${ }^{8}$ Among these eight assigned to prepare the legal basis of the new international organization the role of Harvard Law School, Professor Manley O. Hudson was most noteworthy.

He played the major role in the formation of the international law operation of the League of Nations and setting up the organization pertaining to the international court of justice. The "Harvard Report" on the law of treaties of 1935 was prepared under his supervision as well. He was also nominated twice as a candidate for the Nobel Peace Prize, just like the British journalist William Stead.

The League of Nations, founded in 1920 following the Paris Peace Conference in 1919, was the largest international organization in human history, aimed at preventing a tragic repeat of World War by arbitrating international disputes. Toward that end the codification of all agreements and regulations conforming to the criteria of justice was commenced. Under the auspices of the Harvard Law School Professors Associations, the "League of Nations Committee of Experts for the Progressive Codification of International Law" was formed. The committee prohibited any secret agreements, which had been the major cause of disputes among the world powers to that time. Starting from 1927, the codification project proceeded in seven areas. ${ }^{9}$ In 1932, it was agreed that the project would continue for a third stage through 1935, with more three areas, including the law of treaties, being added (Sansing, 1981). ${ }^{10}$ The work on the law of treaties was assigned to Illinois State University Professor James Wilford Garner, who was designated as "reporter". In 1935, under his supervision, the results of their work were published in the Harvard Draft Convention on the Law of Treaties.

James W. Garner (1871-1938) was born in Mississippi, went to the University of Chicago, and then completed his doctorate at Columbia University. ${ }^{11}$ His major was political science originally, but at Illinois State University he taught international law, foreign policy, and theory of comparative government, among other. In 1927 James Garner published the excellent work Prize Law during the World War and subsequently was appointed as a member of the advisory panel for the Progressive Codification of International Law alongside with those from the Harvard Law School Professors Association. This led him to be designated as "reporter" of the team's study on the law of treaties in 1932. The report on the law of treaties under his supervision cited three treaties as instances that could not possibly have gone into effect in history, namely: (1) 1773 treaty coerced by Russia to divide Poland as the Russian army was besieging the Polish parliament; (2) 1905 Protectorate Treaty signed under the threat on the Korean Emperor and high officials by the Japanese ambassador plenipotentiary with the aid of armed forces; and (3) the 1915 treaty U.S. government trying to get approved while U.S. military forces occupied the Haitian parliament. ${ }^{12}$ Of these, the analysis of (2) was primarily on the basis of the 1906 thesis of French international law scholar Francis Rey.

\footnotetext{
${ }^{8}$ The eight members were: Ruth Bache-Wig, David Hunter Miller, Glenn Coleman, Charles G. Stratton, F. C. Hicks, Laura Turnbull, Manley O. Hudson, Frank L. Warrin, Jr.

9 The seven areas were: nationality, territorial waters, diplomatic privileges and immunities, the responsibility of states for damages done in their territories to the person or prosperity of foreigners, piracy, exploitation of products of the seas, procedures for the calling of international conferences and the drafting of treaties.

10 The three new areas were: (1) the law of extradition, (2) Jurisdiction with respect to crime, and (3) the law of treaties.

11 This description of James Garner is based on his chapter (authored by David G. Sansing) in Lives of Mississippi Authors, 1817-1967 (Editor James B. Lloyd, University of Mississippi, Jackson, 1981).

12 The American Journal of International Law (Vol. 29, p. 1157). Supplement: Research in International Law (1935).
} 
James Garner, who was fluent in French, interacted often with French scholars and went on a number of lecture tours in addition. ${ }^{13}$ Francis Rey both an international law scholar and a practicing attorney, was part of the French delegation to the Paris Peace Conference of 1919, and in the 1930s, he was the secretary of the International Danube Commission. Thus it is a highly plausible assumption that James Garner may have come in contact with him in early 1930s (Uno Fukuju, 1993). When James Garner published the results of the group's studies on the law of treaties on November 7, 1935, he sent one volume ${ }^{14}$ to the project manager Manley O. Hudson who replied with the following letter: ${ }^{15}$

Your handsome volume on Treaties has just reached my hands, and I can't tell you how thrilled I am. It looks absolutely superb. What grand fun it has been to work with you. I shall remember it as long as I live as one of the happiest episodes of my life.

\section{The Report on the Law of Treaties by the United Nations International Law Commission}

The codification project by the League of Nations entered its fourth stage in 1940. The person in charge of this project, Manley O. Hudson, was nominated as a judge of Permanent Court of International Justice in October 1936 around the time of completion of the third stage of the project. ${ }^{16} \mathrm{He}$ only accepted the nomination in 1940 when the fourth stage of the codification would be starting. With Japan's invasion of China (the Sino-Japanese War) in July 1937 and Germany's incursion into Poland in September 1939, the world was once again entering a state of large-scale war. It can be assumed that Professor Manley O. Hudson, who spent more than 20 years in organizing international law, could not overlook these ominous signs and thus finally accepted the nomination as the judge.

On October 24, 1945, the United Nations was founded with the aim of building a new global peace structure, with the consent of the four great countries - the United States, the United Kingdom, the Soviet Union, and China. The League of Nations remained in existence at the time of the founding of new organization. A general assembly was convened at the Geneva Headquarters for nine days starting from April 10, 1946, with delegates from 35 member countries (out of 43 total) attending to express their respect and subsequently dissolve the organization (Sinohara Hatsue, 2010).

During this period of transition, Professor Manley O. Hudson played a bridging role in the field of international law. He worked both for the United Nations' General Assembly and International Law Commission, and also the American Bar Association. As the chairman of the "(American) Bar's Committee for the Progressive Development of International Law", he directly appealed to North American lawyers to support U.N. International Law Commission. He collected those opinions and presented them to the Committee on the

\footnotetext{
${ }^{13}$ From 1920-1921, Garner took part in the lecture series organized by James Hazen Hyde. He traveled to various regional French universities, Paris, and Belgium and lectured in French. Following this, he spent two years from 1922-1923 in India through the Tagore River program and lectured at Calcutta University. Based on these lectures overseas, he published Idées et Institutions Politiques Americans (1921) (Recent Developments in International Law). In 1924, he took charge of the the Goldwin Smith Lectures on International Law at Cornell University, and the following year, he was awarded by the French government with the Chevalier de la Legion d' Honneur.

14 The "volume" was not really a separate book but rather the section entitled "Law of Treaties" in The American Journal of International Law (Vol. 29). Supplement: Research in International Law (1935). This supplement also contained the reports on the other areas studies started in stage three of the codification project. The titles for the three reports were: I. Draft Convention on Extradition, With Comment II. Draft Convention on Jurisdiction with Respect to Crime, With Comment III. Draft Convention on the Law of Treaties, With Comment.

15 The address it was sent to was: American University Union, 173 Boulevard St. Germain, Paris, France.

${ }^{16}$ From the James W. Garner Papers, correspondence sent by Manley Hudson to James Garner dated October 8, 1938, University of Illinois Archives.
} 
Progressive Development of International Law and its Codification (often known as the "Committee of Seventeen"). After hearing his report, the Committee created the draft of the Statute of the International Law Commission. The draft was approved by the U.N. General Assembly on November 21, 1947. In this manner the establishment of an international law system initiated by the League of Nations and spanning some 20 years was carried over to the U.N. through this draft.

In 1963, the U.N. International Law Commission produced (the 15th) "Commission Report on the Law of Treaties" to be presented to the General Assembly. Within the report were examples of "those treaties that could not go into effect", which directly quoted the "Harvard Draft Convention on the Law of Treaties" of the League of Nations (Document A/5509, Report of ILC on its 15th Session) as it is. Namely, under Chapter 2 of the Law of Treaties, Section B, the draft article Part 2 on "Invalidity and termination of treaties", in Article 35 in the section on "individual pressure on country representatives", the example cases found in the Harvard Research Draft lists were adopted as it is. ${ }^{17}$ Another example — on March 15, 1939, Germany coerced the president and foreign minister of Czechoslovakia to sign a treaty to dissolve the nation Czechoslovakia and make Bohemia and Moravia into German protectorates - was added to the above list of treaties that could not possibly go into effect. ${ }^{18}$

The U.N. International Law Commission attached its opinion as to the cited cases for invalidity and termination of treaties on this "report" as Commentary to its own report ${ }^{19}$ and submitted this to the General Assembly (Document A/5509). A resolution on this was drafted and was unanimously adopted on November $18,1963 .^{20}$ This was a moment that should have been witnessed in person by Manley O. Hudson, who dedicated his life to the codification of international law. However, he had passed away three years earlier in April 1960 at the age of 74, after having laid down the necessary basic foundation for this momentous event.

\section{Conclusion}

This study focused on two issues. The first is the Japanese Empire's illegal activity in deliberately forcing Korea to sign flawed treaties in the process of usurping the sovereignty of the Great Han Empire following the Russo-Japanese War in February 1904. The other is the process by which the international peace movement started in the early 1900s among Western intellectuals led to the founding of the League of Nations in 1920 in response to World War I and the subsequent realization of a new international legal order based on a new paradigm for international relations. Korea became Japan's "colony", even though the world peace movement was in the process of creating the League of Nations, as the Japanese Empire engaged in drastic illegal actions - namely, using military threat under martial law imposed under the disguised pretext of pursuing "Oriental Peace". The resistance staged by Korean side against the forced treaties on five occasions resulted in various issues of disqualification or defectiveness in the original texts of these treaties.

\footnotetext{
${ }^{17}$ Yearbook of the International Law Commission 1963 (Vol. II, p. 197). New York: United Nations, 1964.

${ }^{18}$ Sasagawa Norigachi (笹川紀勝) “The Coercion of Hitler's Treaties and modern 'Coercion of States'—An Examination of the Forced Nature of the Korea Protectorate Treaty” (p. 661), co-edited by Yi Tae-jin, Sasagawa Norigachi Hangukbyeonghabgwa Hyeondae “Korea's Annexation and Today” (Taehaksa,, March 2009, Japanese version-December 2008, Akashi Shoten 明石書店).

${ }_{19}$ Report of the Commission to the General Assembly: Report of International Law Commission on its 15th Session (Document A/5509), Yearbook of the International Law Commission 1963 (Vol. II, p. 189, Provision 17). New York: United Nations, 1964.

${ }^{20}$ (1) Yearbook of the International Law Commission 1963 (Vol. II, p. 187). New York: United Nations, 1964, “Also issued as Official Records of the General Assembly, 18th Session, Supplement No.9"; (2) Yearbook of the International Law Commission 1963 (p. 503). New York: United Nations, 1965, "Documentary References"; (3) Resolution 1902 (XVIII), Yearbook of the United Nations 1963 (pp. 503-504). New York: United Nations, 1965.
} 
San Francisco Peace Treaty with Japan of 1951 was signed basically under the policy not to place Japan responsible for its colonial rule, with reparations for military damage incurred being limited to that which occurred after 1927. Those illegal activities perpetrated by Japan in the process of colonizing Korea from 1904 to 1910 were left out of the discussion. Even reparations for the Korean people who suffered enormous pains and damages after 1927 were left out of the equation. This was the effective outcome of Japan's falsified propaganda toward the Western society that "Korea's annexation by Japan" in 1910 was done lawfully, and that the Korean people welcomed Korea's becoming a protectorate of Japan and themselves becoming the Japanese Emperor's subjects.

Did the Korean side fail to respond by taking action aimed at international society? At the time of the forced conclusion of the treaties, the Korean Emperor sent personally-written papers to all the heads of state with whom diplomatic ties had been established. Furthermore, when the Second Hague International Peace Conference was held in February 1907, he dispatched special envoys who made speeches regarding the illegally coerced Protectorate Treaty of 1905 in itemized detail, although done outside the formal arena. In January 1918, U.S. President Wilson declared the principle of national self-determination, and when the Paris Peace Conference was held the following year, Korean independence activists established the Provisional Korean Government in Shanghai, China and moved more enthusiastically than any other time. To convey the will of Korean independence, the provisional government installed in Paris the Korean Mission (La Mission Coréenne) and sent "The Petition of the Korean People and Nation for liberation from Japan and for the reconstitution of Korea as an independent state" to the chairman of the Conference, President Wilson, and representatives of important countries. The petition sent to President Wilson dated May 12, 1919, by the representative Kim Kyu-sik, still exists, along with a separate letter listing major items that was also sent. ${ }^{21}$

The petition, comprised of as many as 14 sections and 20 articles, asserted that the "annexation treaty" was signed through "Fraud and Force" and thus to be considered "Null and Void" and thereby be subject to "Abrogation". He elucidated that the Korean people under the Japanese rule are not living any better but are subsisting in "enslavement" 22 . Furthermore, he warned the Western powers to be vigilant against Japan, whose intention was to obtain hegemony in Asia by the occupation of China for its population and resources, to move onward to the continent with China being used as lever, and furthermore to advance to Australia and the west coast of the U.S. with its people emigrating there, thus changing the Pacific Ocean to the Sea of Japan as the final goal. ${ }^{23}$

How did the Paris Peace Conference respond for this earnest "petition" by the Korean People? The Korean Mission (La Mission Coréenne)'s effort is known to have been to no avail as the Western powers disregarded

\footnotetext{
${ }^{21}$ Kim Kyushik departed from Shanghai on February 1, 1919, and arrived in Paris on March 13th. By this time the conference had already started. As such, the Petition sent to President Wilson was also drafted later. See Jung-sik Lee (1974), Life of Kim Kyusik (p. 168). Sinku munwhasa.

22 "Enslavement" is the word at the Cairo Declaration in 1943. The similar description was already emerged at the third Clause-II of the Petition of the Korean People and Nation in 1919; "Except in the sense that cattle or slaves must be taken care of if they are to be of any value to their owners, the welfare of the Korean People is not an aim of government with Japan". In 1921 the delegate to Great Britain from Korean Commission to America and Europe stated following about Korean peoples' situation: "We are being dragged down to the level of slaves" (The closing remark of the APPEAL OF THE KOREAN PEOPLE FOR LIBERATION FROM JAPAN AND FOR THE RECONSTITUTION OF KOREA sent to the premiers of the British Empire who attended the Conference at London).

${ }^{23}$ This letter was published in the July 1919 edition of the Korea Review. An original copy of the letter and the Petition is presently stored at the Hoover Institution Library at Stanford University. This author received a photocopy from Carole Shaw, author of The Foreign Destruction of Korean Independence (Seoul National University, 2007).
} 
the issue. In truth, the Paris Peace Conference was so preoccupied with the numerous urgent problems stemming from the world powers' competition for territory to date that there was no spare time to pay attention to the issue of a "Far East colony". On June 28, 1919, close to the end of the Conference, the Secretary-General of the Conference (Paul Dutasta) sent a letter stating, "The Korean Issue is not of the nature to be dealt with at the Peace Conference. Please refer the matter to the League of Nations which is to be founded soon (1920)", addressed to the representative Kim Kyu-sik of the Korean Mission. It is noteworthy that this letter corresponds to the official reply to the "petition" sent by the Provisional Korean Government.

Thereafter, the League of Nations put all its efforts into the codification of international law to establish the solid legal basis of the new international relations and produced the Harvard Draft Convention on the Law of Treaties in 1935 as the result of research studies on the law of treaties. The judgment of this Harvard report that the Protectorate Treaty of 1905, which served as the determining cause of the Japanese annexation of Korea, was one of three historical illegal treaties that should have not gone into effect can be regarded as the official reply of the League of Nations to the recovery of national sovereignty of Korea brought up by the Korean petition.

Around this time Japan followed the path similar to that which was predicted by the Korean "Petition" in 1919. Japan's aggression policy geared toward direct control of Manchuria directly led to the birth of Manchukuo ("State of Manchuria") in 1932 and its subsequent withdrawal from the League of Nations. In that same year, the League of Nations chose the law of treaties as a new field in the third stage of its legal codification project, and the report which was produced three years later declared the "Protectorate Treaty" (the determining factor in the Japanese annexation of Korea) as null and void. This outcome of the legal codification project by the League of Nations makes us realize not only its academic purpose but also its efforts of coping with realities maintain global peace.

As was stated in the main text, the main contents of the 1935 League of Nations' Draft Convention on the Law of Treaties were passed onto the United Nations International Law Commission Report in 1963 and thereafter adopted in a resolution by the U.N. General Assembly. If both the League of Nations and the United Nations in 1935 and 1963, respectively, regarded the Protectorate Treaty of 1905 as illegal, international society should have respected the verdict. However, the San Francisco Peace Treaty with Japan of 1951, which occurred in between 1935 and 1963, did not show any recognition of the illegality of that Protectorate Treaty of 1905. The San Francisco Peace Treaty with Japan consists of 27 Articles but not a single clause signifying the legal importance of the treaty can be found. The 1935 Law of Treaties report by the League of Nations was the achievement of American professors and legal scholars in their pertaining areas of expertise, representing the core of intellectual society. Furthermore, their work was transferred over to the United Nations by the practically same group of people. Although 1951 San Francisco Peace Treaty with Japan was designed to deal with the mandate of the times of coping with the communization of East Asia, the fact that it did not mention any single word regarding the process of Japan's securing of its colonies and its fascist rule over them cannot help but be called a historic mistake. This requires sincere reexamination because it amounts to denying the achievements in the world peace movement led by the U.S. itself in the first half of the 20th century.

The United Nations was founded in 1945 at the San Francisco Opera House. The center of the 20th century peace movement was moving geographically from Europe to the U.S. In that same place San Francisco Peace Treaty with Japan of 1951 was concluded. In the "Address of the President Truman at the Opening of the Conference on the Japanese Peace Treaty", he stated that "the nations represented at this Conference ... and 
others came together here, in this very hall, to set up the United Nations as the first essential step toward a firm and lasting peace. Today, we meet here again to take another step along the road to peace". However, whether or not the "San Francisco (Treaty) System" which resulted from this Conference corresponds to the spirit of the foundation of the United Nations is a matter which needs to be scrutinized.

President Truman's "Address at the Opening of the Conference" can be considered as the "preamble" to the San Francisco Treaty (System). In the first half of his address, he emphasized the considerations for Japan. In other words, he emphasized that it was the immediate task of the United Nations to rebuild Japan as a liberal democratic country nourished by a stable economy to be part of the defense system in the Pacific region against communist attack. He even indicated that the treaty recognized the principle that Japan should make reparations to countries which suffered from its aggression, yet the Japanese people would not face a "hopeless" burden of reparations (which would crush their economy).

When President Truman dispatched his delegation (headed by Edwin E. Pauley) to Japan to exact reparations in November 1945, he claimed to advocate a policy of severe punishment for the criminal acts perpetrated by Japanese fascism. However, it is a well-known truth that this policy was revised in consideration of the communization of China and Eastern Europe, which was justifiable in a historical sense considering the circumstances of that time. However, the circumstantial logic of that time does not mean that U.S. could simply disregard the basic spirit of the League of Nations and the United Nations, whose creation the United States had been leading for decades since the beginning of the 20th century.

Toward the end of his address, President Truman stated the following about Korea: "There are other steps which need to be taken. The most important of these is the restoration of peace and security in Korea". This was pointing out the importance for the U.N. forces to win the ongoing Korean War. Other than this, there was no other mention of Korea in his long address of 12 pages.

Thus, the San Francisco Peace Treaty system is so biased that it is not an exaggeration to say that none of Japan's criminal acts were even recognized at all.

In 1952 the U.S. advised Korea and Japan to enter into diplomatic relations based on the new San Francisco Peace Treaty. The two sides continued to meet repeatedly without results due to the extreme discrepancy in each side's views, only to finally reach an agreement in 1965. During the early stages of the negotiations, in response to Japan's initial offensive, Korea brought up the validity issues in the treaties of 1905 and 1910, arguing these should be declared "null and void" as was meant in the Petition of 1919. Korea thought that the starting point of the negotiations should be Japan's acknowledgement of its historic offenses. Japan's refusal to budge on this matter led to repeated unfruitful meetings. Finally in 1965, the "Treaty between Korea and Japan" materialized, with the addition of the term "Already" in front of "null and void" (i.e., "Already null and void" in Article 2 of "Treaty on Basic Relations"). The governments of both countries were questioned by their respective national assemblies as to the exact time frame of the term "already". The concerned authorities from each government gave answers different from each other. The Korean side asserted that "already" meant at the time of coerced signing of treaties, whereas the Japanese government official (Ministry of Foreign Affairs treaties bureau chief) asserted, "already" referred to the time of the establishment of the Government of the Republic of Korea on August 15, 1948.

Furthermore, the "Economic Cooperation Money" (US\$ $300 \mathrm{~m}$ in grant aid, $\$ 200 \mathrm{~m}$ in loans, $\$ 300 \mathrm{~m}$ in loans in private trust $=\$ 800 \mathrm{~m}$ total) hammered out at this negotiation was interpreted differently. The Korean Government referred this as the reparations for the colonial reign, whereas Japan referred to it as 
"Congratulatory Money for Independence". The Japanese Government, with its past history - particularly its militarism history as - having already been exonerated through the San Francisco Peace Treaty already, had no intention at all to express an apology to Korea. This kind of distorted view of history by Japan has been continuously the source of various disputes among the East Asian Countries, even as of now.

Japan was a member country of the United Nations in 1963 when the U.N. International Law Commission submitted the report on the law of treaties to the U.N. General Assembly, which adopted the resolution regarding the report. Even though the Japanese Government was well aware of the verdict rendered by the U.N. that the Protectorate Treaty of 1905 was illegal one, it continued to disregard U.N. verdict in answering to its national assembly as to the results of its negotiations with Korea in 1965. In the absence of strictly scrutiny and criticism from international law circles, Japan's tacitly and deceptively violent stance in the post-war era will continue and any improvement in the international relations among the three Eastern Asian Countries seems hardly likely.

\section{References}

Deokkyu, C. (2014). The Paris peace conference (1919) and Kim Gyushik’s Korean independence diplomacy. Seoyangsayeongu, 35, 136-138.

Hudson, M. O. (1925). The prospect for international law in the twentieth century-Jacob Schiff foundation lectures at Cornell University. The Cornell Law Quarterly, X.

Hudson, M. O. (1935). By Pacific means. New Haven: Yale University Press.

Japanese Army Ministry. (1911). Meiji Reign, 37th-38th years, Annals of the Army Administration and policies (Vol. 10). Tokyo: Shonando Shoten (1983 Reprinted).

Oe sinobu. (1983). Interpretation on the Meiji 37th-38th years, annals of the army administration and policies. Tokyo: Shonando Shoten.

Sansing, D. G. (1981). Lives of Mississippi authors, 1817-1967. Jackson: University of Mississippi.

Sinohara Hatsue. (2020). Kokusai lenmei (pp. 263-264). Jukoshinsyo.

Stead, W. T. (1900). Mr. Carnegie’s Conundrum £40,000,000 What Shall I Do With It? London: Review of Reviews Office.

United Nations. (1964-1965). Yearbook of the international law commission 1963 (Vol. II, p. 189). New York: United Nations.

Uno Fukuju. (1993). Francis Rey's “The International Law Situation of the Great Han Empire"-An argument on the illegality of the treaty of the 1905 protectorate to Korea in the view of international law. Senso Sekinin Kenkyu, 2, 80.

YI, T. J. (2009). The illegality of the signing of the treaties usurping Korea's sovereignty from 1904-1910. In T. J. YI and N. Sasagawa (Eds.), Korea's annexation and reexamination from modern historical international law perspective. Korea: Taehaksa Publisher (Korean language version 2009); Japan: Akashi Shoten Publisher (Japanese version 2008).

YI, T. J. (2014). Yoshida shoin and Tokutomi Soho-The ideological base of the modern Japanese invasion to neighboring countries including Korea. Tsuru bunka daikaku kenkyu kiyo, 80, 10.

YI, T. J. (2016). A study on Japan's forced annexation of Korea (Chapter 3). Seoul: Jisiksaneopsa.

YUN, D. W. (2011). Governor-General Terauchi Masatake's Forced Annexation Maneuvering and the Illegality of Korean Annexation. Samyong Publisher. 